\title{
Paideusis
}

\section{A Reply to Bridging Gulfs Within and Between East and West : Replies to Attila Horvath (2)}

\section{Ulf P. Lundgren}

Volume 2, Number 2, 1989

URI: https://id.erudit.org/iderudit/1073413ar

DOI: https://doi.org/10.7202/1073413ar

See table of contents

Publisher(s)

Canadian Philosophy of Education Society

ISSN

0838-4517 (print)

1916-0348 (digital)

Explore this journal

Cite this article

Lundgren, U. (1989). A Reply to Bridging Gulfs Within and Between East and West : Replies to Attila Horvath (2). Paideusis, 2(2), 15-15.

https://doi.org/10.7202/1073413ar 


\section{Ulf P. Lundgren}

\section{Stockholm Institute of Education}

To be a Swedish educator is to be trapped in the gulf of thinking: "on one hand" and "on the other hand." We have been trying to walk a narrow third way. On one hand, we have a welfare state (even if in a stage of fragmentation and dissolution) that presents itself as capable of forming an equal society. On the other hand, we have a capitalistic economy and a differentiated society. Academically, we have no tradition in educational philosophy which is either analytic or marxist.

I am sorry to have to admit that in this vacuum between policy-makers and educational reality, we have not missed educational philosophers. Our question is: Can we understand the consequences of our education without them? It is in this vacuum that I will interpret Horvath's call for a third way. The new challenge for educational philosophy is not to find some meta-language but find its purpose in relation to the realities of education. And that purpose seems not to be embedded in either analytic or marxist philosophy. We are struck, like Horvath, by the sense that in both traditions there is "a persistent and stubborn alienation from reality." So, "let us seek something they both reject."

Irrespective of how we define the relation between state and society, 1 assert that it is not possible to understand or explain the conditions for modern education without the concepts of state, society, and individual.

Education is the encounter of the individual and the society mediated by the state. To analyse the values reproduced in this meeting is not only an empirical endeavour. It demands conceptual analyses. This is to bring educational philosophy back to the classical standpoint of giving other sciences strength and rigor. The difference is that we need to advance criteria for critical analyses.

There may be a gulf between east and west only if we accept the limited perspectives of the analytic and marxist educational philosophers. 